\title{
Effect of Groundnut + Millets Intercropping System on Yield and Economic Advantage in Central Dry Zone of Karnataka under Rainfed Condition
}

\author{
K.V. Shwethanjali ${ }^{1}$, A.H. Kumar Naik ${ }^{2^{*}}$, T. Basavaraj Naik ${ }^{3}$ and M. Dinesh Kumar ${ }^{3}$ \\ ${ }^{1}$ Department of Agronomy, College of Agriculture, Shivamogga, India \\ ${ }^{2}$ All India Coordinated Research Project on Groundnut, Hiriyur, India \\ ${ }^{3}$ University of Agricultural and Horticultural Sciences, Shivamogga, India \\ *Corresponding author
}

\section{A B S T R A C T}

\begin{tabular}{|l|}
\hline K e y w o r d s \\
$\begin{array}{l}\text { Groundnut, Millets, } \\
\text { Intercropping. Equivalent } \\
\text { yield, LER, ATER, } \\
\text { Economics }\end{array}$ \\
\hline Article Info \\
\hline $\begin{array}{l}\text { Accepted: } \\
\text { 20 August } 2018 \\
\text { Available Online: } \\
\text { 10 September } 2018\end{array}$ \\
\hline
\end{tabular}

A field experiment was conducted during Kharif 2017 at Zonal Agricultural and Horticultural Research Station, Babbur farm, Hiriyur to study effect of groundnut + millets intercropping system on yield and economic advantage in Central dry zone of Karnataka under rainfed condition. The experiment was laid out in randomized block design with ten treatments comprising of three millets viz., finger millet, little millet and foxtail millet with groundnut in the replacement series of 5:2 and 6:1 row proportion and their sole crops replicated thrice. Intercropping of groundnut + foxtail millet with $6: 1$ row proportion showed significantly higher groundnut pod yield $\left(1,744 \mathrm{~kg} \mathrm{ha}^{-1}\right)$, groundnut pod equivalent yield $\left(1,876 \mathrm{~kg} \mathrm{ha}^{-1}\right)$ and area time equivalent ratio (1.10). On the other hand groundnut + foxtail millet with 5:2 row proportion recorded significantly higher land equivalent ratio (1.16).Among the intercropping treatments, economics of the systems also showed that groundnut + foxtail millet (6:1)was most profitable system in terms of gross return (Rs. 91,454 ha ${ }^{-1}$ ), net return (Rs. 50,469 ha-1) and B: C ratio (2.23).

\section{Introduction}

Growing of crops as a sole crop found to be risky under rain fed condition due to low and erratic rainfall, which ultimately results in low productivity. Under such condition in order to achieve higher productivity, intensification and diversification of crops is essential. This includes crop rotation, relay cropping and intercropping of major crops with other compatible crops. However, several factors like cultivar, seeding ratios, planting pattern and competition between mixture components affect the choice as well as growth of species in intercropping (Carr et al., 2004). Intercropping is a system of growing more than one crop species on the same piece of land at the same time. The major objectives of intercropping are to produce an additional crop, to optimize the use of natural resources and to stabilize the yield of crops and to overcome the risk.

Central Dry Zone of Karnataka (Zone-4) is intensively blessed with meager amount of rainfall compelled with poor soil resource base. The local community has developed different cropping system by choosing crops 
such as groundnut, maize, pigeon pea and mustard. These intercropping systems involve smart risk protection combinations. In general, groundnut provides sustainability and ensures better monetary returns. However, to provide stability in the returns, it is always advisable that cereal or short duration compatible pulse crop is introduced as a component crop with groundnut. Groundnut crop can accommodate rapidly growing short duration crops like millets and would prove to be a viable intercropping system. In this context present investigation was taken up to study the effect of groundnut + millets intercropping system on yield and economic advantage in Central dry zone of Karnataka under rainfed condition.

\section{Materials and Methods}

The field experiment was conducted at Zonal Agricultural and Horticultural Research station, Babbur farm, Hiriyur during kharif 2017 under rain fed condition. The station is situated at $13^{\circ} 57^{\prime} 32^{\prime}$ 'North latitude and $70^{\circ}$ 37' 38' East longitude and an altitude of 606 meters above mean sea level (MSL). The soil of the experimental site is vertisol with slightly alkaline $\mathrm{pH}(8.10)$, organic carbon (1.90 $\left.\mathrm{g} \mathrm{kg}^{-1}\right)$, available nitrogen $\left(258 \mathrm{~kg} \mathrm{ha}^{-1}\right)$, available phosphorus $\left(35 \mathrm{~kg} \mathrm{ha}^{-1}\right)$ and available potassium (315 $\left.\mathrm{kg} \mathrm{ha}{ }^{-1}\right)$. Intercropping of millets like finger millet (ML-365), little millet (Sukshema) and foxtail millet (HMT 100-1) with groundnut (G-2-52) in 5:2 and 6:1 row proportion on vertisols was studied under rain fed condition. The treatments included in the experiment were $\mathrm{T}_{1}$ : Sole groundnut, $\mathrm{T}_{2}$ : Sole finger millet, $\mathrm{T}_{3}$ : Sole little millet, $\mathrm{T}_{4}$ : Sole foxtail millet, $\mathrm{T}_{5}$ : Groundnut + finger millet (5:2), $\mathrm{T}_{6}$ : Groundnut + little millet (5:2), $\mathrm{T}_{7}$ : Groundnut + foxtail millet $(5: 2), \mathrm{T}_{8}$ : Groundnut + finger millet (6:1), $\mathrm{T}_{9}$ : Groundnut + little millet (6:1) and $\mathrm{T}_{10}$ : Groundnut + foxtail millet $(6: 1)$. The experiment was laid out in a randomized complete block design with three replications. The data on growth and yield attributes were recorded. Statistical analysis was done as per the methodology suggested by Gomez and Gomez (1984).

\section{Results and Discussion}

The results obtained from the present study have been discussed in detail under following heads:

\section{Effect of intercropping on yield of groundnut}

Groundnut pod and haulm yield in sole and intercropping varied significantly (Table 1). Among various treatments, significantly higher groundnut pod yield (1862 $\left.\mathrm{kg} \mathrm{ha}^{-1}\right)$ and haulm yield (2618 $\mathrm{kg} \mathrm{ha}^{-1}$ ) was recorded in sole groundnut. This could be due to optimum plant population in sole groundnut and compared to intercropped groundnut. Similar results were also reported by Patil et al., (2010) and Shivaraj (2015). In intercropping, relative yield decrement was noticed. However, groundnut + foxtail millet (6:1) recorded significantly higher groundnut pod and haulm yield $\left(1,744 \mathrm{~kg} \mathrm{ha}^{-1}\right.$ and $2,194 \mathrm{~kg}$ $\mathrm{ha}^{-1}$, respectively) which was on par with the groundnut + little millet $\left(1,683 \mathrm{~kg} \mathrm{ha}^{-1}\right.$ and $2,136 \mathrm{~kg} \mathrm{ha}^{-1}$, respectively). This might be due to higher yield of groundnut in the intercropping system and thereby envisages effective utilization of the resources along with millets. Similar findings have been reported by Shiva Kumar and Yadahalli (1996).

\section{Effect of intercropping on yield of millets}

Growing of millets as sole crop recorded significantly higher grain and straw yield as compared to intercropping treatments. Among intercropping treatments groundnut + millets intercropping at 5:2 row ratio recorded higher 
grain and straw yield as compared to 6:1 row ratio (Table 1). Higher yield achieved in 5:2 row ratio compared to $6: 1$ row ratio was mainly due to more space available between two millets rows, thus there is a better availability of light, efficient use of resources and favourable inter and intra species competition, which had a possible effect on grain yield. The results were evidenced with studies of Mahto et al., (2007) and Ramamoorthy et al., (2002)

\section{Effect of different treatments on groundnut equivalent yield}

Performance and profitability of intercropping was assessed by different evaluation indices
(Table 1). Groundnut + foxtail millet in $6: 1$ row ratio significantly recorded higher groundnut pod equivalent yield $\left(1877 \mathrm{~kg} \mathrm{ha}^{-1}\right)$. However, it was statistically parallel with sole groundnut (1862 $\mathrm{kg} \mathrm{ha}^{-1}$ ), intercropping of little millet and finger millet with groundnut (1822 and $1810 \mathrm{~kg} \mathrm{ha}^{-1}$, respectively) in 6:1 row ratio.

The difference in GEY was mainly due to differences in the yield of groundnut, component crop yield and price of individual component crops.

The results as obtained in the present study could be very well supported by studies made by Manjunath and Salakinkop (2017).

Table.1 Yield of groundnut and millets as influenced by groundnut + millets intercropping

\begin{tabular}{|l|c|c|c|c|c|c|c|}
\hline \multicolumn{1}{|c|}{ Treatments } & $\begin{array}{c}\text { Groundnut } \\
\text { pod yield } \\
\left(\mathrm{kg} \mathrm{ha}^{-1}\right)\end{array}$ & $\begin{array}{c}\text { Groundnut } \\
\text { haulm } \\
\text { yield } \\
\left(\mathrm{kg} \mathrm{ha}^{-1}\right)\end{array}$ & $\begin{array}{c}\text { Grain } \\
\text { yield } \\
\left(\mathrm{kg} \mathrm{ha}^{-1}\right)\end{array}$ & $\begin{array}{c}\text { Straw } \\
\text { yield } \\
\left(\mathrm{kg} \mathrm{ha}^{-1}\right)\end{array}$ & LER & ATER & $\begin{array}{c}\text { GPEY } \\
\left(\mathrm{kg} \mathrm{ha}^{-1}\right)\end{array}$ \\
\hline T1: Sole groundnut & 1862 & 2618 & - & - & 1.00 & 1.00 & 1862 \\
\hline T2: Sole finger millet & 1290 & 1763 & 2235 & 2611 & 1.00 & 1.00 & 1152 \\
\hline T3: Sole little millet & 1334 & 1804 & 1252 & 1572 & 1.00 & 1.00 & 619 \\
\hline T4:Sole foxtail millet & 1486 & 1957 & 1584 & 1813 & 1.00 & 1.00 & 641 \\
\hline $\begin{array}{l}\text { T5: Groundnut + } \\
\text { finger millet (5:2) }\end{array}$ & 1590 & 2042 & 761 & 894 & 1.03 & 1.03 & 1683 \\
\hline $\begin{array}{l}\text { T6: Groundnut + } \\
\text { little millet (5:2) }\end{array}$ & 1683 & 2136 & 477 & 598 & 1.10 & 1.02 & 1569 \\
\hline $\begin{array}{l}\text { T7: Groundnut + } \\
\text { foxtail millet (5:2) }\end{array}$ & 1744 & 2194 & 570 & 659 & 1.16 & 1.09 & 1717 \\
\hline $\begin{array}{l}\text { T8: Groundnut + } \\
\text { finger millet (6:1) }\end{array}$ & 104.5 & 82.2 & 424 & 544 & 1.04 & 1.04 & 1809 \\
\hline $\begin{array}{l}\text { T9: Groundnut + } \\
\text { little millet (6:1) }\end{array}$ & 322.1 & 253.3 & 282 & 385 & 1.13 & 1.08 & 1822 \\
\hline $\begin{array}{l}\text { T10: Groundnut + } \\
\text { foxtail millet (6:1) }\end{array}$ & 1862 & 2618 & 327 & 451 & 1.14 & 1.10 & 1876 \\
\hline S.Em \pm & 1290 & 1763 & 56.98 & 70.55 & 0.02 & 0.02 & 89.18 \\
\hline CD at 5 \% & 1334 & 1804 & 170.8 & 211.5 & 0.06 & 0.06 & 264.97 \\
\hline
\end{tabular}

LER: Land equivalent ratio, ATER: Area time equivalent ratio, GPEY: Groundnut pod equivalent yield 
Table.2 Economic advantage of groundnut + millets intercropping system

\begin{tabular}{|l|c|c|c|c|}
\hline \multicolumn{1}{|c|}{ Treatments } & $\begin{array}{c}\text { Cost of } \\
\text { cultivation } \\
\left(\text { Rs. ha }^{-1}\right)\end{array}$ & $\begin{array}{c}\text { Gross } \\
\text { returns } \\
\left(\text { Rs. ha }^{-1}\right)\end{array}$ & $\begin{array}{c}\text { Net returns } \\
\left.\text { (Rs. ha }^{-1}\right)\end{array}$ & $\begin{array}{c}\text { B:C } \\
\text { ratio }\end{array}$ \\
\hline T1: Sole groundnut & 42,300 & 90,709 & 48,409 & 2.14 \\
\hline T2: Sole finger millet & 28,230 & 59,238 & 31,008 & 2.10 \\
\hline T3: Sole little millet & 27,310 & 32,269 & 4,959 & 1.18 \\
\hline T4:Sole foxtail millet & 27,520 & 33,951 & 6,431 & 1.23 \\
\hline T5: Groundnut + finger millet(5:2) & 39,689 & 82,868 & 43,179 & 2.09 \\
\hline T6: Groundnut + little millet (5:2) & 39,629 & 77,036 & 37,407 & 1.94 \\
\hline T7: Groundnut + foxtail millet (5:2) & 39,628 & 84,255 & 44,627 & 2.13 \\
\hline T8: Groundnut + finger millet (6:1) & 40,985 & 88,294 & 47,309 & 2.15 \\
\hline T9: Groundnut + little millet (6:1) & 40,954 & 88,632 & 47,678 & 2.16 \\
\hline T10: Groundnut + foxtail millet (6:1) & 40,985 & 91,454 & 50,469 & 2.23 \\
\hline
\end{tabular}

Effect of different treatments on land equivalent ratio

LER implies the relative land area under sole crops that is required to produce the yields achieved in intercropping under same level of management (Willey, 1979). All the intercropping treatments in the present study recorded greater than one value of LER indicating the yield advantage in all intercropping treatments (Table 1).

Intercropping of groundnut + foxtail millet in $5: 2$ row ratio recorded significantly higher LER 1.16 over sole crop, closely followed by groundnut + foxtail millet (1.14) and groundnut + little millet (1.13) in 6:1 row ratios. It implies intercropping of groundnut with millets is giving yield advantage and land use efficiency of 16,14 and 12 per cent, respectively. Higher yield advantage in intercropping system and their differences could be due to the component crops differed in their use of growth resources and utilized them efficiently as it could be resulting in yields per unit area than that produced by their sole crops and also due to mutualistic and complementary effect of component crops in the system. The result as obtained in the present study was also documented in the studies made by Patil et al., (2010).

\section{Effect of different treatments on land equivalent ratio}

In the present investigation, intercropping treatments recorded higher ATER values over sole cropping treatments (Table 1). Significantly higher ATER recorded in groundnut + foxtail millet (1.10) at $6: 1$ row ratio followed by groundnut + foxtail millet (1.09) and groundnut + little millet (1.08) at 5:2 and 6:1 row ratio, respectively (Table 2). This indicates that not only the efficient use of land but also efficient use of additional time to the extent of 10,9 and 8 per cent, respectively. Higher ATER was mainly attributed to higher equivalent ratio values and yield of component crops in intercropping system and it indicated not only the efficient use of land but also efficient use of time. This result is in concurrence with Prasanna Kumar et al., (2008) and Patil et al., (2010).

\section{Economics of different treatments}

Among the different treatments groundnut + foxtail millet at 6:1 row ratio significantly 
recorded higher gross returns (Rs. 91,454 $\mathrm{ha}^{-1}$ ) and net (Rs. 50,469 ha $^{-1}$ ) returns closely followed by sole groundnut (Rs. 90,709 ha and 48,409 $\mathrm{ha}^{-1}$,respectively), groundnut + little millet (Rs. 88,632 ha ${ }^{-1}$ and 47,678 ha-1, respectively) at 6:1 row ratio as compared 5:2 row ratio (Table 2). This was mainly due to higher yield and price of groundnut. These results are in conformity with findings of Prasanna Kumar et al., (2008) and Patil et al., (2010).

Intercropping of groundnut with foxtail millet noticed higher B: C (2.23) followed by little millet and finger millet (2.16 and 2.15, respectively) at $6: 1$ row ratio. On the other hand lower B: C (1.18) was noticed with sole little millet. The above findings are in accordance with the Yadav et al., (2015) and Padhi et al., (2010)

The present study clearly indicate that intercropping of groundnut + foxtail millet at $6: 1$ row ratio is the best combination for getting higher yield and economic advantage followed by groundnut + little millet under same row ratio.

\section{References}

Carr, P.M., Horsley, R.D. and Poland, W. W., 2004, Barley, oat and cereal-pea mixtures as dryland forages in the Northern Great Plains. Agron. J., 96: 677-684.

Mahto, D.K., Ahmad, S. and Prasad, J., 2007, Effect on growth, yield attributes and yield of finger millet genotypes with pigeonpea and black gram under intercropping system. J. appl. Biol., 17(1-2): 35-39.

Manjunath, M., G. and Salakinkop, S. R., 2017, Growth and yield of soybean and millets in intercropping systems. $J$. Farm Sci., 30(3): 349-353.
Padhi, A. K., Panigrahi, R. K. and Jena, B. K., 2010, Effect of planting geometry and duration of intercrops on performance of pigeonpea-finger millet intercropping systems. Indian J. Agric. Res., 44(1): 43 $-47$.

Patil, N. B., Halikatti, S. I., Sujay, Y.H., Prasanna Kumar, B.H., Sanjay, C. Topagi and Pushpa, V., 2010, Influence of intercropping on the growth and yield of little millet and pigeonpea. Int. J. Agric. Sci., 6(2): 602-604.

Patil, N. B., Halikatti, S. I., Sujay, Y.H., Prasanna Kumar, B.H., Sanjay, C. Topagi and Pushpa, V., 2010, Influence of intercropping on the growth and yield of little millet and pigeonpea. Int. J. Agric. Sci., 6(2): 602-604.

Prasanna Kumar, B. H., Halikatti, S. I. and Ninganur, B. T., 2008, Sustainable intercrop association of pigeonpea (Cajanus cajan L.) in little millet (Panicum sumatrence L.). Karnataka J. Agric. Sci., 22(4): 887-888.

Ramamoorthy, K., Christopher Lourduraj, A., Alagudurai, S., Kandasamy, O. S. and Murugappan, V., 2002. Intercropping pigeonpea (Cajanus cajan) in fingermillet (Eleusine coracana) on productivity and soil fertility under rainfed condition. Indian J. Agron., 49(1): 28-30.

Shiva Kumar, B. G. and Yadahalli, Y. H., 1996, Performance of finger millet genotypes under late sown dryland conditions as influenced by intercrops and intercropping systems. Indian $J$. Agric. Res., 4:46-64.

Shivaraj, D. H., 2015, Intercropping of groundnut with minor millets on alfisols of Northern Transition Zone of Karnataka. M.Sc (Agri.) Thesis, Uni. Agric. Sci., Dharwad.

Willey, R. W., 1979, Intercropping - Its importance and research needs. Part I 
competition and yield advantages. Field Crop Abst., 32(1): 1-10.

Yadav, B. L., Patel, B. S., Shaukat Ali and Yadav, S. K., 2015, Intercropping of legumes and oil seed crop in summer pearlmillet [Pennisetum glaucum (L.) R. Br. Emend. Stuntz]. Leg. Res., 38(4): 503-508.

\section{How to cite this article:}

Shwethanjali, K.V., A.H. Kumar Naik, T. Basavaraj Naik and Dinesh Kumar, M. 2018. Effect of Groundnut + Millets Intercropping System on Yield and Economic Advantage in Central Dry Zone of Karnataka under Rainfed Condition. Int.J.Curr.Microbiol.App.Sci. 7(09): 29212926. doi: https://doi.org/10.20546/ijcmas.2018.709.363 